\title{
The impact of paracentesis flow rate in patients with liver cirrhosis on the development of paracentesis induced circulatory dysfunction
}

\author{
Maha Mohammad Elsabaawy'1, Shimaa Rashad Abdelhamid', Ayman Alsebaey'1, Eman Abdelsamee', \\ Manar Abdelaal Obada', Tary Abdelhamid Salman', and Eman Rewisha' \\ Department of Hepatology, ${ }^{2}$ Department of Clinical Biochemistry, National Liver Institute, Menoufia University, Shebeen El-Kom, Egypt
}

Background/Aims: Ascites is a dreadful complication of liver cirrhosis associated with short survival. Large volume paracentesis (LVP) is used to treat tense or refractory ascites. Paracentesis induced circulatory dysfunction (PICD) develops if no plasma expanders are given with ominous complications. To study the effect of ascites flow rate on PICD development.

Methods: Sixty patients with cirrhosis and tense ascites underwent LVP of $8 \mathrm{~L}$ were randomized into 3 equal groups of different flow rate extraction; group I $(80 \mathrm{~mL} /$ minute), group II (180 mL/minute) and group III ( $270 \mathrm{~mL} / \mathrm{minute})$. Plasma renin activity (PRA) was measured baseline and on day six. PICD was defined as increase in PRA $>50 \%$ of the pretreatment value.

Results: In group I through 3 ; the mean age was ( $52.5 \pm 9.4$ vs. $56.4 \pm 8.5$ vs. $55.8 \pm 7.1$ years; $P>0.05)$, mean arterial pressure ( $81.4 \pm 5.6$ vs. $81.5 \pm 7$ vs. $79.5 \pm 7.2 \mathrm{mmHg} ; P>0.05)$, MELD (17.6 \pm 4.1 vs. $15.8 \pm 4.1$ vs. $14.7 \pm 4.5)$. Baseline PRA was comparable $(1,366.0 \pm 1244.9$ vs. $1,151.3 \pm 1,444.8$ vs. $951.9 \pm 1,088 \mathrm{pg} / \mathrm{mL} ; P>0.05)$. There was no statistically significant $(P>0.05)$ flow mediated changes $(\Delta)$ of creatinine $(0.23 \pm 0.27$ vs. $0.38 \pm 0.33$ vs. $0.26 \pm 0.18 \mathrm{mg} / \mathrm{dL}), \operatorname{MELD}(1.25 \pm 5.72$ vs. $1.70 \pm 2.18$ vs. $1.45 \pm 2.21)$ or PRA ( $450.93 \pm 614.10$ vs. $394.61 \pm 954.64$ vs. $629.51 \pm 1,116.46 \mathrm{pg} / \mathrm{mL})$. PICD was detected in a similar frequency in the three groups $(P>0.05)$. On univariate logistic analysis only female sex was a fairly significant PICD predictor (Wald 3.85 , odds ratio $3.14 ; P=0.05)$.

Conclusions: The ascites flow rate does not correlate with PICD development. (Clin Mol Hepatol 2015;21:365-371)

Keywords: Paracentesis induced circulatory dysfunction; Ascites; Large volume paracentesis; Flow rate

\section{INTRODUCTION}

Ascites is a common dreadful complication of liver cirrhosis. It is associated with poor quality of life and short survival..$^{1-3}$ Therapeutic paracentesis can be used in patients with tense or refractory ascites. ${ }^{4}$ Large volume paracentesis (LVP) of more than $5 \mathrm{~L}$ is associated with paracentesis induced circulatory dysfunction (PICD) development unless plasma expanders are given. ${ }^{1,5-7}$ If less than $5 \mathrm{~L}$ of ascites are tapped, usually PICD does not occur, and thereby artificial plasma expanders, saline, and albumin are equally effective. ${ }^{8}$

PICD is characterized by reduction of effective arterial blood

\section{Abbreviations:}

CO, cardiac output; IAP, intra-abdominal pressure; LVP, Large volume paracentesis; MAP, mean arterial pressure; PICD, Paracentesis induced circulatory dysfunction; PRA, Plasma renin activity; SVR, systemic vascular resistance

\section{Corresponding author: Ayman Alsebaey}

Department of Hepatology, National Liver Institute, Menoufia University, Shebeen El-Kom, Egypt, 32511

Tel: +201003751248 , Fax: +20482234586

E-mail: asebaey@liver-eg.org 
volume with subsequent activation of vasoconstrictor and antinatriuretic factors. Clinically it provokes rapid ascites recurrence rate, development of dilutional hyponatremia, hepatorenal syndrome with increased mortality. ${ }^{9}$

For preventing PICD development, albumin is given in a dose of 6-8 g/L ascites removed. ${ }^{4-9}$ Since costly alternatives were studied like low dose albumin $(2-4 \mathrm{~g} / \mathrm{L}){ }^{10,11}$ terlipressin, $^{11-15}$ noradrenaline, ${ }^{15,16}$ midodrine, ${ }^{11,17-19}$ synthetic colloids, ${ }^{11,20-26}$ and saline. ${ }^{27,28}$ $\beta$-blockers should be avoided in patients with refractory ascites. $^{29,30}$

Does the paracentesis flow rate affect the development of PICD? This was the aim of the study.

\section{PATIENTS AND METHODS}

Sixty patients with HCV related liver cirrhosis and tense ascites admitted to the National Liver Institute hospital for LVP were prospectively included in this study. After institutional review board approval, written informed consent was obtained.

Diagnosis of cirrhosis was based on clinical, laboratory, and ultrasonographic findings. ${ }^{31}$ Inclusion criteria were the presence of tense ascites determined by clinical examination and abdominal ultrasound, requiring frequent therapeutic paracentesis, age less than 70 years and older than 18 years old, and absence of arterial hypertension, history of coronary disease, cardiac failure, respiratory disease, hepatic encephalopathy, sepsis, spontaneous bacterial peritonitis (defined by polymorphonuclear cell count $>250$ / $\mathrm{mm}^{3}$ in ascites), ${ }^{32}$ elevated creatinine concentration $>1.5 \mathrm{mg} / \mathrm{dL}$ and gastrointestinal bleeding within 7 days before the study.

The patients were randomized to 3 groups namely group I (slow flow rate, $n=20$ ), group II (medium flow rate, $n=20$ ), group III (rapid flow rate, $n=20$ ).

All patients were on a low-sodium diet (34 mmol/day) for at least 7 days outpatient before inclusion in the study. Changes of the effective arterial blood volume were evaluated by measuring plasma rennin activity (PRA) at day of paracentesis (day 0; baseline) and on the day of hospital discharge (day 6).

On the day 0; a baseline workup, including body weight, blood pressure, heart rate, electrocardiogram, liver tests (bilirubin, albumin, aspartate aminotransferase, alanine aminotransferase, alkaline phosphatase), and renal function tests (urea and creatinine), were conducted. Blood samples were collected after an overnight fast and bed rest for at least 30 minutes in the supine position for measuring PRA. Blood samples were put into chilled ethylenedi- aminetetraacetic acid tubes, centrifuged at 2,500 rpm for $10 \mathrm{~min}$ at $-3^{\circ} \mathrm{C}$, and stored at $-20^{\circ} \mathrm{C}$.

Fixed volume $8 \mathrm{~L}$ paracentesis was then done under local anesthesia and strict aseptic conditions, ${ }^{33}$ followed by albumin at a dose of $8 \mathrm{~g} / \mathrm{L}$ ascites removed. Owing to the unavailability of the suction bottles, the ascitic fluid flowed through the cannula to sterile urine collection bag through a drip line. In group I, the flow rate was $80 \mathrm{~mL} /$ minute with $18 \mathrm{G}$ cannula, in group II, the flow rate was $180 \mathrm{~mL} /$ minute with $16 \mathrm{G}$ cannula, and finally in group $\mathrm{III}$, the flow rate was $270 \mathrm{~mL} /$ minute with $14 \mathrm{G}$ cannula.

From day 1 to day 5 , the patients were monitored daily for body weight, daily urine output volume, blood pressure, heart rate and development of complications.

On the day of hospital discharge (day 6); blood pressure, heart rate, and weight were recorded. Electrocardiogram, renal and liver function tests were done, and blood was collected for PRA measurement.

\section{Outcome measures}

The primary end point was taken as development of PICD that was defined as an increase in PRA of $>50 \%$ of the pretreatment value. $^{9}$

\section{Methods of measurement}

Renin test procedure was done using ELISA [DRG ${ }^{\circledR}$ Renin ELISA (EIA-5125) Germany] on ELISA reader Multiskan FC (Cat. no. 51119000), Thermo Fisher Scientific (Finland). The procedures were done according to the manufacturer's instructions.

Liver function tests included alanine aminotransferase (ALT), aspartate aminotransferase (AST), bilirubin, albumin and kidney functions including urea and creatinine, were measured using Cobas Integra 800 Auto analyzer (Roche Diagnostics Ltd - Germany. Catalogue number; $\mathrm{M}, 87432)$. Prothrombin test was done using BFT $^{*}$ II Analyzer (Dade Behring Marburg GmbH, D-35041 Marburg, Germany).

\section{Statistical analysis}

Data was statistically analyzed using SPSS version 17 for Windows (SPSS Inc., Chicago, IL, USA). Comparisons between two groups were performed using the Student's $t$-test for continuous data, Mann-Whitney test for nonparametric variables and the $\chi^{2}$ and Fisher test for categorical data. Comparisons of the variables 
in the same group were performed using the paired $t$-test for continuous data and Wilcoxon test for non-homogenous data. Comparisons between multiple groups were performed by usage of ANOVA test for parametric variables and Kruskal Wallis Test for nonparametric variables. Odds ratio test was used to assess the development of PICD with groups. Multivariate logistic regression analysis was used for detection of PICD predictors. Results were expressed as mean \pm standard deviation. All $P$-values are 2 tailed, with values $<0.05$ considered statistically significant.

\section{RESULTS}

At inclusion there was no statistically significant difference $(P$ $>0.05$ ) among all groups (group I through III) regarding the mean age ( $52.5 \pm 9.4$ vs. $56.4 \pm 8.5$ vs. $55.8 \pm 7.1$ years), male sex $(N=12$ vs. 12 vs. 11), mean arterial pressure [MAP] (81.4 \pm 5.6 vs. $81.5 \pm 7$ vs. $79.5 \pm 7.2 \mathrm{mmHg})$ and heart rate $(84.9 \pm 7.9$ vs. $86.1 \pm 9.6$ vs. $86.5 \pm 8.7$ beat $/ \mathrm{min}$ ) (Table 1).

There was significant difference of the baseline weight $(80.6 \pm 12.4$ vs. $84.2 \pm 13.4$ vs. $91 \pm 9.6 \mathrm{~kg} ; P=0.03)$ being lower in group I than group III $(80.6 \pm 12.4$ vs. $91 \pm 9.6 \mathrm{~kg})$.

The liver, kidney functions, INR and electrolytes were statistical- ly nonsignificant among all groups $(P>0.05)$. Bilirubin $(4.5 \pm 3.6$ vs. $3.3 \pm 2.5$ vs. $2.9 \pm 2.2 \mathrm{mg} / \mathrm{dL})$, serum albumin $(2.1 \pm 0.4$ vs. $2.2 \pm 0.3$ vs. $2.3 \pm 0.4 \mathrm{~g} / \mathrm{dL})$, INR ( $1.9 \pm 0.8$ vs. $1.6 \pm 0.3$ vs. $1.6 \pm 0.3)$, urea $(58.6 \pm 24.1$ vs. $62.1 \pm 28.1$ vs. $50.3 \pm 20.1 \mathrm{mg} / \mathrm{dL})$, creatinine $(0.9 \pm 0.3$ vs. $0.9 \pm 0.2$ vs. $0.9 \pm 0.3 \mathrm{mg} / \mathrm{dL}), \mathrm{Na}(121.3 \pm 6.6$ vs. $123 \pm 5.5$ vs. $116.3 \pm 25.1 \mathrm{mmol} / \mathrm{L})$, and $\mathrm{K}(4.4 \pm 0.7$ vs. $4 \pm 0.5$ vs. $4.5 \pm 0.7 \mathrm{mmol} / \mathrm{L})$.

The Child-Pugh score $(10.8 \pm 1.2$ vs. $10.6 \pm 1.2$ vs. $10.3 \pm 1.3)$, MELD $(17.6 \pm 4.1$ vs. $15.8 \pm 4.1$ vs. $14.7 \pm 4.5)$ and MELD Na (25.2 \pm 2.9 vs. $24.4 \pm 2.6$ vs. $23.3 \pm 4)$ were comparable among all groups $(P>0.05)$.

The PRA at inclusion was comparable among all groups $(1,366.0 \pm 1,244.9$ vs. $1,151.3 \pm 1,444.8$ vs. $951.9 \pm 1,088 \mathrm{pg} / \mathrm{mL} ; P$ $>0.05)$. Table 2 shows the flow (treatment) induced changes with each group. The delta $(\Delta)$ represents change from day 0 at inclusion to day 6 at discharge ( $\Delta=\mathrm{D} 6-\mathrm{D} 0)$. The minus (-) signs mean decreases value at day 6 .

There was no significant statistically difference of the treatment induced changes $(P>0.05)$ among all groups regarding weight $(1.25 \pm 1.77$ vs. $1.80 \pm 2.44$ vs. $0.80 \pm 1.40 \mathrm{~kg})$, MAP $(-2.92 \pm 10.33$ vs. $-4.51 \pm 9.10$ vs. $1.34 \pm 11.26 \mathrm{mmHg}$ ), heart rate $5.90 \pm 7.66$ vs. $6.70 \pm 8.11$ vs. $4.10 \pm 4.36$ beat $/ \mathrm{min})$, bilirubin ( $0.51 \pm 0.61$ vs $0.28 \pm 0.41$ vs. $0.62 \pm 0.71 \mathrm{mg} / \mathrm{dL})$, serum albumin $(0.05 \pm 0.08$ vs.

Table 1. Demographic data of all patients according to the group of treatment at the time of inclusion

\begin{tabular}{|c|c|c|c|c|}
\hline Variables & $\begin{array}{c}\text { Group I } \\
n=20\end{array}$ & $\begin{array}{c}\text { Group II } \\
n=20\end{array}$ & $\begin{array}{c}\text { Group III } \\
n=20\end{array}$ & $P$-value \\
\hline Age (years) & $52.5 \pm 9.4$ & $56.4 \pm 8.5$ & $55.8 \pm 7.1$ & $>0.05$ \\
\hline Males (N) & $12(60 \%)$ & $12(60 \%)$ & $11(55 \%)$ & $>0.05$ \\
\hline Weight (kg) & $80.6 \pm 12.4$ & $84.2 \pm 13.4$ & $91 \pm 9.6$ & $0.03^{\mathrm{a}}$ \\
\hline MAP $(\mathrm{mmHg})$ & $81.4 \pm 5.6$ & $81.5 \pm 7.0$ & $79.5 \pm 7.2$ & $>0.05$ \\
\hline Pulse (b/m) & $84.9 \pm 7.9$ & $86.1 \pm 9.6$ & $86.5 \pm 8.7$ & $>0.05$ \\
\hline Bilirubin (mg/dL) & $4.5 \pm 3.6$ & $3.3 \pm 2.5$ & $2.9 \pm 2.2$ & $>0.05$ \\
\hline Albumin (g/dL) & $2.1 \pm 0.4$ & $2.2 \pm 0.3$ & $2.3 \pm 0.4$ & $>0.05$ \\
\hline INR & $1.9 \pm 0.8$ & $1.6 \pm 0.3$ & $1.6 \pm 0.3$ & $>0.05$ \\
\hline CP score & $10.8 \pm 1.2$ & $10.6 \pm 1.2$ & $10.3 \pm 1.3$ & $>0.05$ \\
\hline Urea (mg/dL) & $58.6 \pm 24.1$ & $62.1 \pm 28.1$ & $50.3 \pm 20.1$ & $>0.05$ \\
\hline Creatinine (mg/dL) & $0.9 \pm 0.3$ & $0.9 \pm 0.2$ & $0.9 \pm 0.3$ & $>0.05$ \\
\hline $\mathrm{Na}(\mathrm{mmol} / \mathrm{L})$ & $121.3 \pm 6.6$ & $123 \pm 5.5$ & $116.3 \pm 25.1$ & $>0.05$ \\
\hline $\mathrm{K}(\mathrm{mmol} / \mathrm{L})$ & $4.4 \pm 0.7$ & $4 \pm 0.5$ & $4.5 \pm 0.7$ & $>0.05$ \\
\hline MELD & $17.6 \pm 4.1$ & $15.8 \pm 4.1$ & $14.7 \pm 4.5$ & $>0.05$ \\
\hline MELD Na & $25.2 \pm 2.9$ & $24.4 \pm 2.6$ & $23.3 \pm 4$ & $>0.05$ \\
\hline PRA (pg/ml) & $1,366.0 \pm 1,244.9$ & $1,151.3 \pm 1,444.8$ & $951.9 \pm 1,088$ & $>0.05$ \\
\hline
\end{tabular}

a: group I vs. III

MAP, mean arterial pressure; INR, international normalized ratio; CP score, Child-Pugh score; PRA, plasma renin activity. 
Table 2. Comparison of the flow induced changes among the different groups

\begin{tabular}{|c|c|c|c|c|}
\hline $\begin{array}{l}\Delta=\text { D6 - D0 } \\
\text { Variables }\end{array}$ & $\begin{array}{c}\text { Group I } \\
n=20\end{array}$ & $\begin{array}{c}\text { Group II } \\
n=20\end{array}$ & $\begin{array}{c}\text { Group III } \\
n=20\end{array}$ & $P$-value \\
\hline$\Delta$ Weight (kg) & $1.25 \pm 1.77$ & $1.80 \pm 2.44$ & $0.80 \pm 1.40$ & $>0.05$ \\
\hline$\triangle \mathrm{MAP}(\mathrm{mmHg})$ & $-2.92 \pm 10.33$ & $-4.51 \pm 9.10$ & $1.34 \pm 11.26$ & $>0.05$ \\
\hline$\Delta$ Pulse $(b / m)$ & $5.90 \pm 7.66$ & $6.70 \pm 8.11$ & $4.10 \pm 4.36$ & $>0.05$ \\
\hline$\Delta$ Bilirubin (mg/dL) & $0.51 \pm 0.61$ & $0.28 \pm 0.41$ & $0.62 \pm 0.71$ & $>0.05$ \\
\hline$\triangle$ Albumin (g/dL) & $0.05 \pm 0.08$ & $0.07 \pm 0.07$ & $0.08 \pm 0.13$ & $>0.05$ \\
\hline$\triangle C P$ score & $1.00 \pm 1.17$ & $0.55 \pm 0.76$ & $0.75 \pm 1.02$ & $>0.05$ \\
\hline$\Delta$ Urea (mg/dL) & $19.15 \pm 27.37$ & $25.95 \pm 14.82$ & $23.00 \pm 18.90$ & $>0.05$ \\
\hline$\Delta$ Creatinine $(\mathrm{mg} / \mathrm{dL})$ & $0.23 \pm 0.27$ & $0.38 \pm 0.33$ & $0.26 \pm 0.18$ & $>0.05$ \\
\hline$\triangle \mathrm{Na}(\mathrm{mmol} / \mathrm{L})$ & $0.95 \pm 1.28$ & $0.80 \pm 1.77$ & $6.40 \pm 24.90$ & $>0.05$ \\
\hline$\Delta K(\mathrm{mmol} / \mathrm{L})$ & $0.20 \pm 0.25$ & $0.44 \pm 0.58$ & $0.17 \pm 0.30$ & $>0.05$ \\
\hline$\triangle M E L D$ & $1.25 \pm 5.72$ & $1.70 \pm 2.18$ & $1.45 \pm 2.21$ & $>0.05$ \\
\hline$\triangle M E L D N a^{*}$ & $0.85 \pm 3.41$ & $1.20 \pm 2.40$ & $1.30 \pm 2.75$ & $>0.05$ \\
\hline$\triangle P R A(p g / m l)$ & $450.93 \pm 614.10$ & $394.61 \pm 954.64$ & $629.51 \pm 1,116.46$ & $>0.05$ \\
\hline
\end{tabular}

"Kruskal Wallis Test.

MAP, mean arterial pressure; CP score, Child-Pugh score; PRA, plasma renin activity.

Table 3. Risk of paracentesis induced circulatory dysfunction development

\begin{tabular}{cccccc}
\hline & $\begin{array}{c}\text { Variable } \\
\mathbf{n}=\mathbf{2 0}\end{array}$ & $\begin{array}{c}\text { Group I } \\
\mathbf{n = 2 0}\end{array}$ & $\begin{array}{c}\text { Group II } \\
\mathbf{n = 2 0}\end{array}$ & Group III & P-value \\
\hline PICD & PICD -ve & $14(70 \%)$ & $15(75 \%)$ & $13(65 \%)$ & $>0.05$ \\
\hline PICD +ve & $6(30 \%)$ & $5(25 \%)$ & $7(35 \%)$ & \\
\hline
\end{tabular}

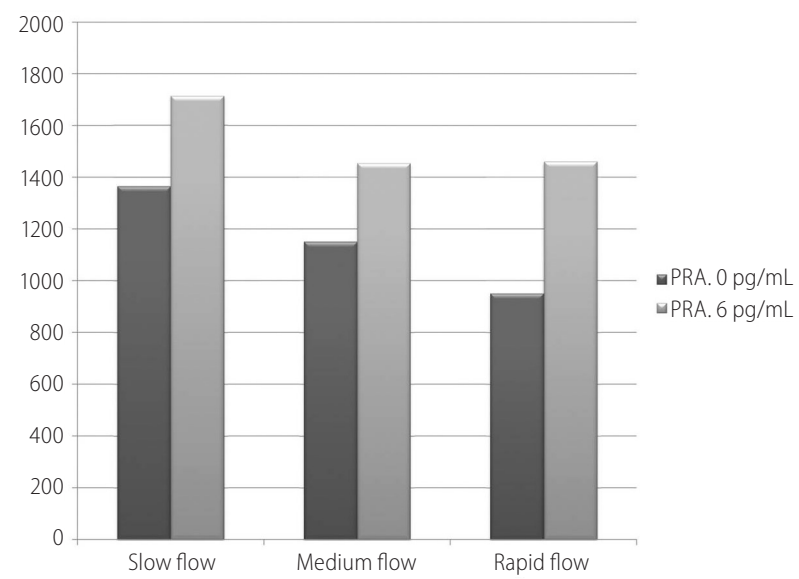

Figure 1. Flow induced changes of the plasma renin activity (PRA) at day 0,6 and the percent increase.

$0.07 \pm 0.07$ vs. $0.08 \pm 0.13 \mathrm{~g} / \mathrm{dL})$, urea $(19.15 \pm 27.37$ vs. $25.95 \pm 14.82$ vs. $23.00 \pm 18.90 \mathrm{mg} / \mathrm{dL})$, creatinine $(0.23 \pm 0.27$ vs. $0.38 \pm 0.33$ vs. $0.26 \pm 0.18 \mathrm{mg} / \mathrm{dL}), \mathrm{Na}(0.95 \pm 1.28$ vs. $0.80 \pm 1.77$ vs. $6.40 \pm 24.90 \mathrm{mmol} / \mathrm{L}), \mathrm{K}(0.20 \pm 0.25$ vs. $0.44 \pm 0.58$ vs. $0.17 \pm 0.30 \mathrm{mmol} / \mathrm{L})$, the Child-Pugh score $(1.00 \pm 1.17$ vs.
$0.55 \pm 0.76$ vs. $0.75 \pm 1.02)$, MELD (1.25 \pm 5.72 vs. $1.70 \pm 2.18$ vs. $1.45 \pm 2.21)$ and MELD Na $(0.85 \pm 3.41$ vs. $1.20 \pm 2.40$ vs. $1.30 \pm 2.75)$

Fortunately there were no significant flow induced changes among all groups (Fig. 1) concerning PRA (450.93 \pm 614.10 vs. $394.61 \pm 954.64$ vs. $629.51 \pm 1116.46 \mathrm{pg} / \mathrm{mL} ; P>0.05)$.

By the application of the PICD definition, about 6 patients developed PICD in group I, 5 in group II and 7 in group III (Table 3). Fruitfully there was no statistical significance among the different groups $(P>0.05)$.

By the logistic univariate regression analysis (Table 4) for the predictors of PICD development, multiple variables were analyzed e.g. age, sex, weight, mean arterial pressure, heart rate, serum bilirubin, albumin, INR, hemoglobin, WBCs, platelets, urea, creatinine, Na, K, Child-Pugh score, MELD and MELD Na. Only female sex was fairly significant predictor of PICD development (Wald 3.85, odds ratio 3.14; $P=0.05$ ). 
Table 4. Univariate analysis for predictors of paracentesis induced circulatory dysfunction development

\begin{tabular}{|c|c|c|c|c|c|c|}
\hline \multirow{2}{*}{$\begin{array}{l}\text { Baseline } \\
\text { Variables }\end{array}$} & \multirow{2}{*}{ B } & \multirow{2}{*}{ Wald } & \multirow{2}{*}{$P$-value } & \multirow{2}{*}{$\begin{array}{c}\operatorname{Exp}(B) \\
\text { odds ratio }\end{array}$} & \multicolumn{2}{|c|}{ 95\% C.I. for EXP(B) } \\
\hline & & & & & Lower & Upper \\
\hline Age & -0.04 & 1.67 & $>0.05$ & 0.96 & 0.9 & 1.02 \\
\hline Female & 1.15 & 3.85 & 0.05 & 3.14 & 1 & 9.87 \\
\hline Weight & -0.01 & 0.12 & $>0.05$ & 0.99 & 0.95 & 1.04 \\
\hline MAP & -0.01 & 0.07 & $>0.05$ & 0.99 & 0.91 & 1.08 \\
\hline Heart rate & 0 & 0.02 & $>0.0$ & 1 & 0.94 & 1.07 \\
\hline Bilirubin & -0.06 & 0.28 & $>0.05$ & 0.95 & 0.77 & 1.16 \\
\hline Albumin & 0.15 & 0.04 & $>0.05$ & 1.16 & 0.27 & 5.02 \\
\hline INR & 0.85 & 1.85 & $>0.05$ & 2.34 & 0.69 & 7.97 \\
\hline $\mathrm{Hb}$ & -0.09 & 0.15 & $>0.05$ & 0.91 & 0.59 & 1.43 \\
\hline WBCs & 0.14 & 2.27 & $>0.05$ & 1.15 & 0.96 & 1.37 \\
\hline Platelets & -0.02 & 3.24 & $>0.05$ & 0.98 & 0.97 & 1 \\
\hline Urea & 0 & 0 & $>0.05$ & 1 & 0.98 & 1.02 \\
\hline Creatinine & 1.18 & 1.02 & $>0.05$ & 3.25 & 0.33 & 31.94 \\
\hline $\mathrm{Na}$ & -0.02 & 0.7 & $>0.05$ & 0.98 & 0.95 & 1.02 \\
\hline K & -0.47 & 1.12 & $>0.05$ & 0.63 & 0.26 & 1.49 \\
\hline CP score & -0.35 & 1.9 & $>0.05$ & 0.71 & 0.43 & 1.16 \\
\hline MELD & 0.03 & 0.26 & $>0.05$ & 1.03 & 0.91 & 1.18 \\
\hline MELD Na & -0.01 & 0.03 & $>0.05$ & 0.99 & 0.83 & 1.17 \\
\hline
\end{tabular}

MAP, mean arterial pressure; CP score, Child-Pugh score; PRA, plasma renin activity.

\section{DISCUSSION}

The advent of ascites portends a bad prognosis with development of spontaneous bacterial peritonitis, dilutional hyponatremia, hepatorenal syndrome and short survival. ${ }^{4,5}$

Therapeutic paracentesis is better than diuretics for rapid and safe ascites relief with less adverse effects. PICD develops if more than $5 \mathrm{~L}$ ascites are tapped without giving plasma expanders. ${ }^{3}$

Noteworthy PICD leads to high ascites recurrence rate, development of hepatorenal syndrome, dilutional hyponatremia, and increased mortality. ${ }^{9}$

Notably most papers discussed how to prevent PICD development by different plasma expanders or the vasoconstrictors, ${ }^{21}$ but few discussed the influence of paracentesis flow rate on PICD development.

Cabrera et al. ${ }^{34}$ postulated that rapid abdominal decompression was a predictor of PICD development. About 11 patients underwent LVP were enrolled. A specially designed pneumatic girdle was used to compress the abdomen to avoid a decrease in intra-abdominal pressure (IAP) during ascites removal. Hemodynamic studies were performed before paracentesis, one hour after ascites flow stopped, and 30 minutes after pneumatic girdle deflation.

One hour after ascites removal, none of the hemodynamic parameters [cardiac output (CO), MAP or systemic vascular resistance (SVR)] was modified significantly. In contrast, 30 minutes after girdle deflation, a significant increase in $\mathrm{CO}$ and a significant decrease in both MAP and SVR. They hypothesized that abrupt abdominal decompression, occurring immediately after tense ascites removal portends PICD development. It may be assumed that mechanical decompression of an already dilated splanchnic vascular bed led to further arterial vasodilatation. ${ }^{34}$

Coll et al. ${ }^{35}$ studied the influence of flow rate of ascites extraction on PICD development. Twenty-two cirrhotic patients with tense ascites underwent LVP were enrolled. Measurements of intra-abdominal pressure and the volume of ascites removed were recorded every $10 \mathrm{~min}$. Hormonal and hemodynamic measurements were performed at baseline and $3 \mathrm{~h}$ after total paracentesis. There was decreased SVR with increased nitrate level in 17 patients. These patients had higher baseline intra-abdominal pressure, shorter duration of paracentesis $(60 \pm 4.9$ vs. $88 \pm 0.4$ min; $P<0.01)$ and higher flow rate of ascites extraction $(1.18 \pm 0.08$ vs. $0.81 \pm 0.12 \mathrm{~L} / \mathrm{min} ; P<0.05)$. The volume of ascites removed was 
similar in patients with and without a decrease in SVR. But unfortunately PRA was measured at day of LVP and the following day so PICD definition ${ }^{9}$ cannot be applied.

In our study we fixed the volume of the ascitic fluid to be removed to avoid its cumulative effect on PICD development. The suction bottles are not available so we used a cannula connected to sterile urine collection bag through a drip line. It is known that the suction bottles needs less time to be filled to the urine bags. It is to be noted that the suction bottles do not depend on the positive abdominal pressure only for the fluid flow but also on the negative vacuum pressure in the bottles. Does this impact? Further studies are needed.

In the three different groups there was no significant flow mediated changes of the liver, kidney functions or the MELD scores. Fortunately the PRA did not differ statistically. The number of PICD development was comparable in all groups. Theoretically the more the flow rate, the more liability for PICD development but this was not the role. Really PICD mechanisms are still not well elucidated. It is not merely a mechanical process but other pathways are present but not detected yet. Carl et al. ${ }^{36}$ was the first to describe the inflammatory process associated with PICD development.

By the logistic regression analysis only the female gender was fairly 3 times more associated PICD development than males. Why? Really no explanation is available although Johnson et al. ${ }^{37}$ reported it.

Really the small number of this is a limitation so studies with larger numbers are warranted.

In conclusion the ascites flow rate does not correlate with PICD development.

\section{Conflicts of Interest}

The authors have no conflicts to disclose.

\section{REFERENCES}

1. Kuiper JJ, de Man RA, van Buuren HR. Review article: Management of ascites and associated complications in patients with cirrhosis. Aliment Pharmacol Ther 2007;26(Suppl 2):183-193.

2. Kuiper JJ, van Buuren HR, de Man RA. Ascites in cirrhosis: a review of management and complications. Neth J Med 2007;65:283-288.

3. Hou W, Sanyal AJ. Ascites: diagnosis and management. Med Clin North Am 2009;93:801-817, vii.

4. Runyon BA. Introduction to the revised American Association for the
Study of Liver Diseases Practice Guideline management of adult patients with ascites due to cirrhosis 2012. Hepatology 2013;57:16511653.

5. European Association for the Study of the Liver. EASL clinical practice guidelines on the management of ascites, spontaneous bacterial peritonitis, and hepatorenal syndrome in cirrhosis. J Hepatol 2010;53:397-417.

6. Runyon BA. Management of adult patients with ascites due to cirrhosis: an update. Hepatology 2009;49:2087-2107.

7. Lindsay AJ, Burton J, Ray CE Jr. Paracentesis-induced circulatory dysfunction: a primer for the interventional radiologist. Semin Intervent Radiol 2014;31:276-278.

8. Moore KP, Aithal GP. Guidelines on the management of ascites in cirrhosis. Gut 2006;55(Suppl 6):vi1-12.

9. Ruiz-del-Arbol L, Monescillo A, Jimenéz W, Garcia-Plaza A, Arroyo $V$, Rodés J. Paracentesis-induced circulatory dysfunction: mechanism and effect on hepatic hemodynamics in cirrhosis. Gastroenterology 1997;113:579-586.

10. Alessandria C, Elia C, Mezzabotta L, Risso A, Andrealli A, Spandre $M$, et al. Prevention of paracentesis-induced circulatory dysfunction in cirrhosis: standard vs half albumin doses. A prospective, randomized, unblinded pilot study. Dig Liver Dis 2011;43:881-886.

11. Alsebaey A, Abdel-Razek W, Bassuni A, Rewisha E, Khalil M, Waked I. Prevention of paracentesis-induced circulatory dysfunction: could we use other albumin alternatives? Egyptian Liver J 2013;3:118-125.

12. Moreau R, Asselah T, Condat B, de Kerguenec C, Pessione F, Bernard $B$, et al. Comparison of the effect of terlipressin and albumin on arterial blood volume in patients with cirrhosis and tense ascites treated by paracentesis: a randomised pilot study. Gut 2002;50:9094.

13. Singh V, Kumar R, Nain CK, Singh B, Sharma AK. Terlipressin versus albumin in paracentesis-induced circulatory dysfunction in cirrhosis: a randomized study. J Gastroenterol Hepatol 2006;21:303-307.

14. Lata J, Marecek Z, Fejfar T, Zdenek P, Brůha R, Safka V, et al. The efficacy of terlipressin in comparison with albumin in the prevention of circulatory changes after the paracentesis of tense ascites--a randomized multicentric study. Hepatogastroenterology 2007;54:19301933.

15. Abdullah MH, Saleh SM, Morad WS. Terlipressin versus norepinephrine to counteract intraoperative paracentesis induced refractory hypotension in cirrhotic patients. Egyptian J Anaesthesia. 2012;1:2935.

16. Singh V, Kumar B, Nain CK, Singh B, Sharma N, Bhalla A, et al. Noradrenaline and albumin in paracentesis-induced circulatory dysfunction in cirrhosis: a randomized pilot study. J Intern Med 2006;260:62-68.

17. Singh V, Dheerendra PC, Singh B, Nain CK, Chawla D, Sharma N, et al. Midodrine versus albumin in the prevention of paracentesis- 
induced circulatory dysfunction in cirrhotics: a randomized pilot study. Am J Gastroenterol 2008;103:1399-1405.

18. Appenrodt B, Wolf A, Grünhage F, Trebicka J, Schepke M, Rabe C, et al. Prevention of paracentesis-induced circulatory dysfunction: midodrine vs albumin. A randomized pilot study. Liver Int 2008;28:10191025.

19. Hamdy H, ElBaz AA, Hassan A, Hassanin O. Comparison of midodrine and albumin in the prevention of paracentesis-induced circulatory dysfunction in cirrhotic patients: a randomized pilot study. J Clin Gastroenterol 2014;48:184-188.

20. Planas R, Ginès P, Arroyo V, Llach J, Panés J, Vargas V, et al. Dextran-70 versus albumin as plasma expanders in cirrhotic patients with tense ascites treated with total paracentesis. Results of a randomized study. Gastroenterology 1990;99:1736-1744.

21. Ginès $A$, Fernández-Esparrach $G$, Monescillo $A$, Vila $C$, Domènech $E$, Abecasis $R$, et al. Randomized trial comparing albumin, dextran 70, and polygeline in cirrhotic patients with ascites treated by paracentesis. Gastroenterology 1996;111:1002-1010.

22. García-Compean D, Blanc P, Larrey D, Daures JP, Hirtz J, Mendoza $E$, et al. Treatment of cirrhotic tense ascites with Dextran-40 versus albumin associated with large volume paracentesis: a randomized controlled trial. Ann Hepatol 2002;1:29-35.

23. Moreau R, Valla DC, Durand-Zaleski I, Bronowicki JP, Durand F, Chaput JC, et al. Comparison of outcome in patients with cirrhosis and ascites following treatment with albumin or a synthetic colloid: a randomised controlled pilot trail. Liver Int 2006;26:46-54.

24. El-Ashry N, El-Damarawy M, Salem M, Mogawer S. Large volume abdominal paracentesis effect on some humoral factors and cardiac performance in patients with liver cirrhosis and tense ascities. J Egypt Soc Parasitol 2007;37:571-584.

25. Abdel-Khalek EE, Arif SE. Ran\{Runyon, 2009 \#66\}\{Runyon, 2009 \#66\}\{Runyon, 2009 \#66\}domized trial comparing human albumin and hydroxyethyl starch $6 \%$ as plasma expanders for treatment of patients with liver cirrhosis and tense ascites following large volume paracentesis. Arab Journal of Gastroenterology 2010;11:24-29.

26. Nasr G, Hassan A, Ahmed S, Serwah A. Predictors of large volume paracantesis induced circulatory dysfunction in patients with massive hepatic ascites. J Cardiovasc Dis Res 2010;1:136-144.
27. Cabrera J, Inglada L, Quintero E, Jimenez W, Losada A, Mayor J, et al. Large-volume paracentesis and intravenous saline: effects on the renin-angiotensin system. Hepatology 1991;14:1025-1028.

28. Sola-Vera J, Miñana J, Ricart E, Planella M, González B, Torras X, et al. Randomized trial comparing albumin and saline in the prevention of paracentesis-induced circulatory dysfunction in cirrhotic patients with ascites. Hepatology 2003;37:1147-1153.

29. Sersté T, Melot C, Francoz C, Durand F, Rautou PE, Valla D, et al. Deleterious effects of beta-blockers on survival in patients with cirrhosis and refractory ascites. Hepatology 2010;52:1017-1022.

30. Sersté T1, Francoz C, Durand F, Rautou PE, Melot C, Valla D, et al. Beta-blockers cause paracentesis-induced circulatory dysfunction in patients with cirrhosis and refractory ascites: a cross-over study. J Hepatol 2011;55:794-799.

31. Schuppan D, Afdhal NH. Liver cirrhosis. Lancet 2008;371:838-851.

32. Rimola A, García-Tsao G, Navasa M, Piddock LJ, Planas R, Bernard B, et al. Diagnosis, treatment and prophylaxis of spontaneous bacterial peritonitis: a consensus document. International Ascites Club. J Hepatol 2000;32:142-153.

33. McGibbon A, Chen GI, Peltekian KM, van Zanten SV. An evidencebased manual for abdominal paracentesis. Dig Dis Sci 2007;52:33073315.

34. Cabrera J, Falcón L, Gorriz E, Pardo MD, Granados R, Quinones A, et al. Abdominal decompression plays a major role in early postparacentesis haemodynamic changes in cirrhotic patients with tense ascites. Gut 2001;48:384-389.

35. Coll S, Vila MC, Molina L, Gimenez MD, Guarner C, Solà R. Mechanisms of early decrease in systemic vascular resistance after total paracentesis: influence of flow rate of ascites extraction. Eur J Gastroenterol Hepatol 2004;16:347-353.

36. Carl DE, Ghosh S, Cheng J, Gehr TW, Stravitz RT, Sanyal A. Postparacentesis circulatory derangements are related to monocyte activation. Liver Int 2014;34:1001-1007.

37. Johnson KB, Mueller JL, Simon TG, Zheng H, King LY, Makar RS, et al. Reduced Albumin Dosing During Large-Volume Paracentesis Is Not Associated with Adverse Clinical Outcomes. Dig Dis Sci 2015;60:2190-2195. 